\begin{tabular}{|l|l|l|l|l|l|}
\hline J. Tek. Ling & Vol. 13 & No. 2 & Hal. 179 - 192 & Jakarta, Mei 2012 & ISSN 1441-318X \\
\hline
\end{tabular}

\title{
METABOLISME PENGELOLAAN SAMPAH ORGANIK MELALUI TEKNOLOGI KOMPOSTING DI WILAYAH INTERNAL PERKOTAAN
}

\author{
(Kajian Pengelolaan Sampah Organik pada Tipologi Kota Sedang, \\ Studi Kasus di Kota Probolinggo, Jawa Timur) \\ Sri Wahyono"), Sulistyoweni Widanarko's), Setyo S. Moersidik²), \\ Surna T. Djajadiningrat ${ }^{2)}$ \\ 1) Peneliti di Pusat Teknologi Lingkungan, \\ Badan Pengkajian dan Penerapan Teknologi \\ 2) Dosen Pascasarjana Program Studi IImu Lingkungan, Universitas Indonesia \\ swahyono@yahoo.com
}

\begin{abstract}
Abstrak
Kegiatan komposting sampah kota umumnya tidak berjalan sinambung karena kegagalan pasar, lemahnya dukungan pemerintah, lemahnya manajemen dan ketidaklayakan teknik yang digunakan. Penelitian ini bertujuan menyusun konsep metabolisme pengelolaan sampah organik melalui teknologi komposting di wilayah internal perkotaan. Metodologi penelitian ini dilakukan dengan metode kuntitatif dan eksploratif deskriptif melalui analisis matematis, analisis multikriteria pengambilan keputusan, analisis aliran material, dan analisis finansial. Penelitian menyimpulkan bahwa metabolisme pengelolaan sampah organik melalui teknologi komposting di wilayah internal perkotaan adalah metabolisme sistem fisik, sosial, dan ekonomi dari kegiatan pengelolaan sampah organik yang bercirikan metabolisme antropogenik untuk keberlanjutan kota sedang.
\end{abstract}

Kata kunci: Pengelolaan sampah organik, metabolisme, aliran material, komposting, analisis multikriteria.

\begin{abstract}
Composting of municipal solid waste activities generally do not run continuously because of market failure, lack of government support, poor management and inability of the techniques used. This study aims to develop the concept of the metabolism of organic waste management through composting technology in internal urban areas. The research methodology was conducted by the method of quantitative and descriptive explorative through mathematical analysis, multicriteria decision analysis, material flow analysis, and financial analysis. The study concluded that the metabolism of organic waste management through composting technology in internal urban areas is the metabolism system of physical, social, economic and environmental of organic waste management activities characterized by anthropogenic metabolism to the sustainability of medium cities.
\end{abstract}

Key words: Organic waste management, metabolism, material flow, composting, analysis of multicriteria 


\section{PENDAHULUAN}

\subsection{Latar Belakang}

Sejalan dengan peningkatan jumlah penduduk dan modernitas kehidupan perkotaan, semakin tinggi pula input material dan energi yang diperlukannya. Efisiensi pemakaian material dan energi di dalam ekosistem perkotaan tidak pernah mencapai seratus persen, di dalamnya selalu terdapat entropi. Oleh karena itu, sampah sebagai bentuk entropi, semakin meningkat timbulannya dan juga semakin meningkat jenis, komposisi dan karakteristiknya. Situasi tersebut tidak diikuti dengan pengelolaan yang memadai sehingga mengakibatkan pencemaran lingkungan yang mengancam ekosistem perkotaan.

Masalah persampahan dapat ditanggulangi dengan peningkatan pelayanan dan peningkatan upaya recovery dan daur ulang material sampah. Komposting memiliki peran penting dalam upaya tersebut karena kemampuannya mengubah sampah organik menjadi soil conditioner yang bermanfaat bagi perbaikan kesuburan tanah. Kegiatan komposting di Indonesia umumnya tidak berjalan sinambung; hal tersebut diakibatkan oleh beberapa sebab, yakni kegagalan pasar, lemahnya dukungan pemerintah, lemahnya manajemen dan ketidaklayakan teknik yang digunakan. .,2,3,4,5) $^{2}$

Kegagalan pemasaran kompos perlu diatasi melalui upaya mobilisasi konsumen kompos di lingkungan internal perkotaan. Masalah kurangnya dukungan pemerintah dan lemahnya manajemen kompos sebagai penyebab lain dari kegagalan komposting dapat didekati pemecahannya dengan kebijakan penerapan sistem desentralisasi dan atau sentralisasi komposting. Namun, mekanisme pemilihan sistem tersebut belum ada. Sementara itu, ketidaklayakan teknologi komposting, dapat didekati pemecahannya dengan seleksi teknologi yang terintegrasi. Namun, mekanisme penyeleksiannya juga belum tersedia.

\subsection{Tujuan}

Penelitian ini bertujuan menyusun konsep metabolisme pengelolaan sampah organik di wilayah internal perkotaan.

Secara khusus penelitian ini bertujuan:

1. Memetakan supply kompos berbahan baku sampah kota dan demand kompos di wilayah internal perkotaan,

2. Menyusun seperangkat kriteria untuk memilih opsi desentralisasi dan sentralisasi komposting,

3. Menyusun seperangkat kriteria untuk menyeleksi berbagai jenis teknologi komposting skala rumah tangga, skala lingkungan dan skala kota, dan

4. Menyusun dan menguji efektivitas dan efisiensi konsep metabolisme pengelolaan sampah organik di wilayah internal perkotaan.

\section{METODE PENELITIAN}

Metode yang dipakai untuk mengkaji pemetaan supply dan demand kompos di wilayah internal perkotaan adalah metode analisis fungsi matematis. Sementara itu, metode yang digunakan dalam penyusunan kriteria desentralisasi dan sentralisasi komposting merupakan modifikasi dari metode yang dikembangkan oleh Department for Communities and Local Government London $^{6}$ ), dan $\mathrm{CIFOR}^{7)}$ yang meliputi metode penyusunan kriteria dan mekanisme analisis multikriteria pengambilan keputusan (multicriteria decision analysis). Metode yang dipakai dalam penyusunan kriteria dan seleksi teknologi komposting sama seperti yang dipakai dalam penyusunan kriteria pemilihan opsi desentralisasi dan sentralisasi komposting.

Sementara itu, konsep metabolisme pengelolaan sampah organik di wilayah internal perkotaan yang tersusun diuji efektivitasnya dengan metode analisis aliran material (Material Flow Analysis/ MFA), dan diuji efisiensinya dengan metode analisis finansial (Financial Analysis). Untuk 
melakukan analisis aliran material digunakan software STAN versi 2.0.1703. Analisis finansial menggunakan modifikasi dari metode yang digunakan oleh Kwon. ${ }^{8)}$

Dalam pengujian konsep metabolisme pengelolaan sampah organik di wilayah internal perkotaan, diterapkan empat skenario, yaitu Skenario 1 (seluruh sampah organik diolah melalui komposting skala lingkungan); Skenario 2 (sebanyak 30\% sampah yang dihasilkan oleh perumahan diolah di rumah tangga dan sisanya beserta seluruh sampah dari sumber lainnya diolah di beberapa plant komposting skala lingkungan); Skenario 3 (seluruh sampah dari berbagai sumber diangkut dan diolah di sebuah plant komposting skala kota); dan Skenario 4 (sebanyak 30\% sampah dari pemukiman diolah di rumah tangga, sedangkan selebihnya dan sampah dari sumber-sumber lainnya diolah di sebuah plant komposting skala kota). Fokus kajian adalah untuk tipologi kota sedang Probolinggo.

\section{HASIL DAN PEMBAHASAN}

\subsection{Pemetaan Supply-Demand Kompos}

Pemetaan supply-demand kompos merupakan bagian dari konsep metabolisme pengelolaan sampah organik terkait dengan peta penyerapan kompos di wilayah internal perkotaan. Status supply dan demand kompos diidentifikasi dengan rasio supply kompos dan demand kompos. Dari hasil analisis, total proyeksi supply kompos (Y1) Kota Probolinggo adalah 11.222.816 $\mathrm{kg} / \mathrm{tahun}$. Proyeksi supply kompos dari perumahan adalah yang paling besar, diikuti oleh pasar. Rinciannya dapat dilihat pada Tabel 1.

Demand kompos dihitung dari konsumen potensial yang meliputi urban agriculture, pengelola TPA, rumah tangga, pengelola RTH, pembibitan tanaman, tambak, budidaya tanaman hias, lanskap, dan jalur hijau. Proyeksi demand kompos terbesar berasal dari urban agriculture diikuti oleh pengelola TPA dan rumah tangga. Total proyeksi demand kompos Kota Probolinggo (Y2) adalah 98.411.468 kg/tahun. Rinciannya dapat dilihat pada Tabel 2 .

Dengan demikian, rasio proyeksi supply kompos (Y1) dan demand kompos (Y2)di Kota Probolinggo adalah 0,11. Rasio tersebut lebih kecil dari 1 yang mengindikasikan bahwa proyeksi kompos yang diproduksi di Kota Probolinggo secara teoritis semuanya dapat diserap di wilayah internal Kota Probolinggo.

Tabel 1. Rincian Proyeksi Supply Kompos di Kota Probolinggo

\begin{tabular}{|l|r|r|r|r|}
\hline Sumber Sampah & $\begin{array}{c}\text { Laju Produksi } \\
\text { Sampah9,10 } \\
\text { (kg/tahun) }\end{array}$ & $\begin{array}{c}\text { Komposisi } \\
\text { Sampah } \\
\text { Organik9 (\%) }\end{array}$ & $\begin{array}{c}\text { Persentase } \\
\text { Produk Kompos* } \\
(\%)\end{array}$ & $\begin{array}{c}\text { Supply Kompos** } \\
(\mathrm{kg} / \text { tahun) }\end{array}$ \\
\hline Perumahan & 33.766 .964 & 73,64 & 32,5 & 8.081 .447 \\
\hline Pasar & 8.781 .541 & 85,20 & 32,5 & 2.431 .608 \\
\hline Pertokoan dan jasa & 1.355 .974 & 27,20 & 32,5 & 119.868 \\
\hline Fasilitas kesehatan & 212.167 & 31,70 & 32,5 & 21.858 \\
\hline Industri & 411.478 & 49,13 & 32,5 & 65.701 \\
\hline Pertamanan & 1.717 .373 & 90,00 & 32,5 & 502.331 \\
\hline & & & Jumlah $=\mathrm{Y} 1$ & 11.222 .816 \\
\hline
\end{tabular}

Keterangan:

* dari hasil penelitian

** supply kompos = laju produksi sampah $\mathrm{x}$ komposisi $\mathrm{x}$ transfer koefisien kompos 
Tabel 2. Proyeksi Demand Kompos di Kota Probolinggo

\begin{tabular}{|c|c|c|c|c|c|}
\hline \multirow{2}{*}{$\begin{array}{l}\text { Konsumen } \\
\text { Kompos }\end{array}$} & \multicolumn{2}{|c|}{ Variabel 1} & \multicolumn{2}{|c|}{ Variabel 2} & \multirow{2}{*}{$\begin{array}{c}\text { Demand } \\
\text { Kompos* }^{*}(\mathrm{~kg} / \\
\text { tahun) }\end{array}$} \\
\hline & Keterangan & Nilai & Keterangan & Nilai & \\
\hline $\begin{array}{l}\text { Tempah } \\
\text { Pemrosesan } \\
\text { Akhir (TPA) }\end{array}$ & $\begin{array}{l}\text { Laju pembuangan } \\
\text { sampah ke TPA (kg/ } \\
\text { tahun) }\end{array}$ & $11.713 .756^{9,10)}$ & $\begin{array}{l}\text { Rasio } \\
\text { penutupan } \\
\text { TPA }\end{array}$ & $0,17^{11,12)}$ & 1.952 .292 \\
\hline $\begin{array}{l}\text { Ruang } \\
\text { Terbuka } \\
\text { Hijau (RTH) }\end{array}$ & Luas lahan RTH $\left(\mathrm{m}^{2}\right)$ & $24.000^{13)}$ & $\begin{array}{l}\text { Laju } \\
\text { pemupukan } \\
\text { RTH (kg/m2/ } \\
\text { tahun) }\end{array}$ & $10,0^{14)}$ & 240.000 \\
\hline $\begin{array}{l}\text { Urban } \\
\text { Agriculture }\end{array}$ & $\begin{array}{l}\text { Luas lahan urban } \\
\text { agriculture }\left(\mathrm{m}^{2}\right)\end{array}$ & $55.665 .800^{13)}$ & $\begin{array}{l}\text { Laju } \\
\text { pemupukan } \\
\text { urban } \\
\text { agriculture } \\
\text { (kg/m2/tahun) }\end{array}$ & $1,70^{15)}$ & 94.473 .908 \\
\hline $\begin{array}{l}\text { Rumah } \\
\text { Tangga }\end{array}$ & Jumlah rumah tangga & $62.527^{13)}$ & $\begin{array}{l}\text { Laju } \\
\text { pemupukan } \\
\text { rumah tangga } \\
\text { (kg/rumah/ } \\
\text { tahun) }\end{array}$ & $24,0^{16)}$ & 1.500 .648 \\
\hline Tambak & $\begin{array}{l}\text { Luas lahan tambak } \\
\left(\mathrm{m}^{2}\right)\end{array}$ & $967.200 .00^{13)}$ & $\begin{array}{l}\text { Laju } \\
\text { pemupukan } \\
\text { tambak(kg/ } \\
\text { m2/tahun) }\end{array}$ & $0,10^{16)}$ & 96.720 \\
\hline $\begin{array}{l}\text { Budidaya } \\
\text { Tanaman } \\
\text { Hias }\end{array}$ & Jumlah tanaman hias & $7.000^{\mathrm{d}}$ & $\begin{array}{l}\text { Laju } \\
\text { pemupukan } \\
\text { tanaman hias } \\
\text { (kg/tanaman/ } \\
\text { tahun) }\end{array}$ & $2,0^{* *}$ & 14.000 \\
\hline Pembibitan & Jumlah bibit tanaman & $57.500^{* *}$ & $\begin{array}{l}\text { Laju } \\
\text { pemupukan } \\
\text { bibit (kg/bibit/ } \\
\text { tahun) }\end{array}$ & $2,0^{* *}$ & 115.000 \\
\hline Jalur Hijau & $\begin{array}{l}\text { Luas lahan jalur hijau } \\
\left(\mathrm{m}^{2}\right)\end{array}$ & $5.000^{* *}$ & $\begin{array}{l}\text { Laju } \\
\text { pemupukan } \\
\text { jalur hijau (kg/ } \\
\text { m2/tahun) }\end{array}$ & $1,26^{15)}$ & 6.300 \\
\hline Lanskap & $\begin{array}{l}\text { Luas lahan lanskap } \\
\left(\mathrm{m}^{2}\right)\end{array}$ & $10.000^{* *}$ & $\begin{array}{l}\text { Laju } \\
\text { pemupukan } \\
\text { lanskap (kg/ } \\
\text { m2/tahun) }\end{array}$ & $1,26^{15)}$ & 12.600 \\
\hline & & & & tal $=Y 2$ & 98.411 .468 \\
\hline
\end{tabular}

Keterangan:

* demand kompos $=$ variable $1 \mathrm{x}$ variabel 2

${ }^{* *}$ dari prediksi 


\subsection{Pemilihan Opsi Desentralisasi dan Sentralisasi Komposting}

Kriteria yang tersusun untuk pemilihan opsi desentralisasi dan sentralisasi komposting terdiri atas 8 (delapan) kelompok kriteria yaitu teknis persampahan, pendanaan pengelolaan sampah, peraturan daerah terkait pengelolaan sampah, kelembagaan pengelola persampahan, peran serta masyarakat dalam pengelolaan sampah, demografi kota, timbulan dan komposisi sampah, dan tata ruang TPA. Dari kriteria tersebut kemudian dirinci menjadi 16 (enambelas) sub-kriteria yang meliputi persentase jumlah TPS tipe 1, tingkat pelayanan sampah, persentase anggaran persampahan, tingkat kualifikasi pegawai lembaga pengelola persampahan, tingkat keberadaan lokasi pengelolaan sampah berbasis masyarakat, tingkat keberadaan lokasi komposting skala lingkungan, jumlah penduduk, kepadatan penduduk, jumlah wilayah dengan timbulan sampah 1-10 ton/ hari, tingkat komposisi sampah organik, keberadaan TPA dan jarak TPA dengan pusat kota.

Kriteria yang tersusun tersebut kemudian diuji kualitasnya dan diberi bobot sesuai dengan tingkat pentingnya dalam penentuan opsi desentralisasi dan sentralisasi komposting. Dengan cara menyandingkan antara lembar fakta Kota Probolinggo yang telah tersusun dengan

Tabel 3. Lembar Fakta Kota Probolinggo untuk Analisis Multikriteria Pemilihan Opsi Desentralisasi dan Sentralisasi

\begin{tabular}{|c|c|c|c|}
\hline No. & Kriteria & Jumlah & Satuan \\
\hline 1. & Persentase jumlah TPS dengan luas $>100 \mathrm{~m} 2$ & $6.15^{9)}$ & $\%$ \\
\hline 2. & Tingkat pelayanan sampah terangkut ke TPA & $22.35^{9,17)}$ & $\%$ \\
\hline 3. & Persentase anggaran persampahan terhadap APBD & $0.71^{9,10,18)}$ & $\%$ \\
\hline 4. & Efektivitas pendapatan retribusi sampah & $2.15^{9,10)}$ & $\%$ \\
\hline 5. & $\begin{array}{l}\text { Ketersediaan peraturan daerah yang mendukung program } \\
\text { pengelolaan sampah }\end{array}$ & ada19, 20) & - \\
\hline 6. & Ketersediaan peraturan daerah yang mendukung program 3R & $\operatorname{ada}^{19,21)}$ & - \\
\hline 7. & Tingkat eselon lembaga pengelola persampahan & eselon ${ }^{3 a}$ & - \\
\hline 8. & Kualifikasi lulusan S-1 pegawai persampahan & $4^{9)}$ & orang \\
\hline 9. & Jumlah lokasi pengelolaan sampah berbasis masyarakat & $42^{22)}$ & lokasi \\
\hline 10 & Jumlah lokasi komposting skala lingkungan & $2^{22)}$ & lokasi \\
\hline 11. & Jumlah penduduk & $216,967^{13)}$ & jiwa \\
\hline 12. & Kepadatan penduduk & $49^{13)}$ & jiwa/ha \\
\hline 13. & Jumlah wilayah dengan timbulan sampah 1-10 ton/hari & $93.10^{9)}$ & $\%$ \\
\hline 14. & Komposisi sampah organik & $74,7^{9,17)}$ & $\%$ \\
\hline 15. & Keberadaan TPA & lokal ${ }^{9)}$ & - \\
\hline 16. & Jarak TPA dengan pusat kota & $1.5^{9)}$ & $\mathrm{km}$ \\
\hline
\end{tabular}

persampahan terhadap APBD, efektivitas pendapatan retribusi sampah, ketersediaan peraturan daerah yang mendukung program pengelolaan sampah, ketersediaan peraturan daerah yang mendukung program $3 \mathrm{R}$, tingkat eselon lembaga pengelola lembar acuan pemberian skor, dilakukan penilaian skor sekaligus pembobotannya terhadap setiap kriteria.

Dari nilai skoring diketahui bahwa opsi desentralisasi komposting mendapatkan nilai skor total 66,75 sedangkan opsi sentralisasi 
mendapatkan nilai skor total 33,25. Dengan hasil demikian, opsi yang direkomendasikan

untuk diterapkan di Kota Probolinggo adalah desentralisasi komposting.

Tabel 4. Matrik Performansi Skor Pemilihan Opsi Desentralisasi dan Sentralisasi Komposting Kota Probolinggo

\begin{tabular}{|c|c|c|c|c|c|c|c|}
\hline \multirow{2}{*}{ No. } & \multirow{2}{*}{ Kriteria } & \multicolumn{2}{|l|}{ Sub-Kriteria } & \multicolumn{2}{|c|}{ Desentralisasi } & \multicolumn{2}{|c|}{ Sentralisasi } \\
\hline & & & Bobot & Skor & Nilai & Skor & Nilai \\
\hline \multirow[t]{2}{*}{1.} & $\begin{array}{l}\text { Teknis } \\
\text { Persampahan }\end{array}$ & $\begin{array}{l}\text { Persentase jumlah TPS } \\
\text { dengan luas }>100 \mathrm{~m} 2\end{array}$ & 0,050 & 30 & 1,50 & 70 & 3,50 \\
\hline & & Tingkat pelayanan sampah & 0,050 & 80 & 4,00 & 20 & 1,00 \\
\hline \multirow[t]{2}{*}{2.} & $\begin{array}{l}\text { Pendanaan } \\
\text { Pengelolaan } \\
\text { Sampah }\end{array}$ & $\begin{array}{l}\text { Persentase anggaran } \\
\text { persampahan terhadap APBD }\end{array}$ & 0,075 & 80 & 6,00 & 20 & 1,50 \\
\hline & & $\begin{array}{l}\text { Efektivitas pendapatan } \\
\text { retribusi sampah }\end{array}$ & 0,025 & 90 & 2,25 & 10 & 0,25 \\
\hline \multirow[t]{2}{*}{3.} & $\begin{array}{l}\text { Peraturan } \\
\text { Daerah Terkait } \\
\text { Pengelolaan } \\
\text { Sampah }\end{array}$ & $\begin{array}{l}\text { Ketersediaan peraturan daerah } \\
\text { yang mendukung program } \\
\text { pengelolaan sampah }\end{array}$ & 0,020 & 80 & 1,60 & 20 & 0,40 \\
\hline & & $\begin{array}{l}\text { Ketersediaan peraturan daerah } \\
\text { yang mendukung program } 3 R\end{array}$ & 0,060 & 80 & 4,80 & 20 & 1,20 \\
\hline \multirow[t]{2}{*}{4.} & $\begin{array}{l}\text { Kelembagaan } \\
\text { Pengelola } \\
\text { Persampahan }\end{array}$ & $\begin{array}{l}\text { Tingkat eselon lembaga } \\
\text { pengelola persampahan }\end{array}$ & 0,050 & 80 & 4,00 & 20 & 1,00 \\
\hline & & $\begin{array}{l}\text { Tingkat kualifikasi pegawai } \\
\text { lembaga pengelola } \\
\text { persampahan }\end{array}$ & 0,050 & 60 & 3,00 & 40 & 2,00 \\
\hline \multirow[t]{2}{*}{5.} & $\begin{array}{l}\text { Peran Serta } \\
\text { Masyarakat } \\
\text { dalam } \\
\text { Pengelolaan } \\
\text { Sampah }\end{array}$ & $\begin{array}{l}\text { Tingkat keberadaan lokasi } \\
\text { pengelolaan sampah berbasis } \\
\text { masyarakat }\end{array}$ & 0,180 & 80 & 14,40 & 20 & 3,60 \\
\hline & & $\begin{array}{l}\text { Tingkat keberadaan lokasi } \\
\text { komposting skala kawasan }\end{array}$ & 0,060 & 50 & 3,00 & 50 & 3,00 \\
\hline \multirow[t]{2}{*}{6.} & Demografi Kota & Jumlah penduduk & 0,105 & 80 & 8,40 & 20 & 2,10 \\
\hline & & Tingkat kepadatan penduduk & 0,035 & 80 & 2,80 & 20 & 0,70 \\
\hline \multirow[t]{2}{*}{7.} & $\begin{array}{l}\text { Timbulan dan } \\
\text { Komposisi } \\
\text { Sampah }\end{array}$ & $\begin{array}{l}\text { Jumlah wilayah dengan } \\
\text { timbulan sampah } 1-10 \text { ton/hari }\end{array}$ & 0,075 & 80 & 6,00 & 20 & 1,50 \\
\hline & & $\begin{array}{l}\text { Tingkat komposisi sampah } \\
\text { organik }\end{array}$ & 0,025 & 60 & 1,50 & 40 & 1,00 \\
\hline \multirow[t]{2}{*}{8.} & Tata Ruang TPA & Keberadaan TPA & 0,035 & 40 & 1,40 & 60 & 2,10 \\
\hline & & Jarak TPA dengan pusat kota & 0,105 & 20 & 2,10 & 80 & 8,40 \\
\hline \multicolumn{5}{|c|}{ Jumlah } & 66,75 & & 33,25 \\
\hline
\end{tabular}




\subsection{Seleksi Teknologi Komposting}

Seperangkat kriteria yang tersusun untuk menyeleksi teknologi komposting terdiri atas 4 (empat) kelompok kriteria yang di dalamnya meliputi kriteria teknis, kriteria lingkungan, kriteria sosial, dan kriteria ekonomi. Keempat kriteria tersebut dirinci menjadi 20 (duapuluh) sub-kriteria yaitu tingkat kematangan teknologi, tingkat kandungan bahan lokal, tingkat fleksibilitas operasi, tingkat kebutuhan lahan, performansi produk kompos, rentang kapasitas plant, tingkat kemudahan operasi komposting, tingkat konservasi material, tingkat konservasi energi, tingkat bau dan pencegahan polusi udara, tingkat pencegahan polusi air dan tanah, tingkat populasi lalat, tingkat penyerapan tenaga kerja, tingkat persepsi masyarakat, tingkat keterlibatan masyarakat, tingkat efek kesejahteraan masyarakat, biaya investasi, biaya operasi dan pemeliharaan, biaya spesifik kompos, dan pasar kompos.

Kriteria yang tersusun tersebut kemudian diuji kualitasnya dan diberi bobot sesuai dengan tingkat pentingnya kriteria. Dengan cara menyandingkan antara lembar fakta teknologi dengan lembar acuan pemberian skor, dilakukan penilaian skor sekaligus pembobotannya terhadap setiap teknologi yang diseksi. Teknologi komposting skala rumah tangga yang diseleksi meliputi komposter Takakura (R1), komposter
'Aerob' (R2), komposter 'Gentong' (R3), komposter 'Jambangan' (R4), komposter 'Statis' (R5), komposter 'Boisca' (R6), dan komposter 'Cat' (R7). Sementara itu, teknologi komposting skala lingkungan yang diseleksi meliputi teknologi komposting Windrow (L1), teknologi komposting Cetak (L2), teknologi komposting Open Box (L3), teknologi komposting Rotary Composter (L4). Teknologi komposting skala kota yang diseleksi meliputi teknologi komposting Windrow (K1), Static Pile (K2), Vertical Flow Reactor (K3), Horizontal Flow Reactor (K4), dan Inclined Flow Reactor (K5).

Dari nilai skoring diketahui bahwa teknologi komposting skala lingkungan dan skala kota terpilih yaitu teknologi komposting sistem Windrow dengan nilai skor 74,35 dan 76,93 . Sementara itu teknologi komposting skala rumah tangga yang memperoleh nilai skor tinggi adalah komposter Takakura $(79,11)$ dan komposter 'Aerobik' $(78,78)$. Dengan pertimbangan beberapa pertimbangan seperti penempatannya dapat dilakukan indoor (di dalam ruangan) dan outdoor (di luar ruangan), tahan terhadap panas dan hujan, masa pakainya lebih awet, tidak perlu penggantian sarana pendukung (kardus), dan lebih mudah mendapatkan wadah komposternya, akhirnya dipilih komposter 'Aerobik' sebagai teknologi komposter yang terpilih. Teknologi-teknologi yang terpilih digunakan dalam penyusunan konsep metabolisme pengelolaan sampah organik.

Tabel 5. Matrik Performansi Skor Terbobotkan Seleksi Teknologi Komposting Skala Rumah Tangga, Skala Lingkungan dan Skala Kota

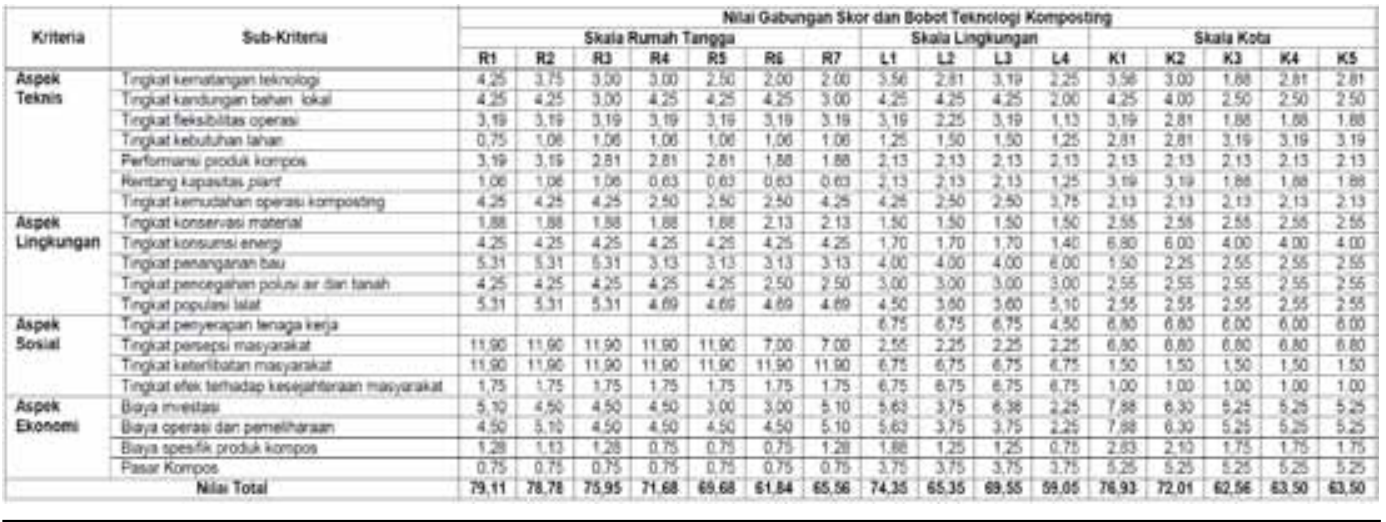

Metabolisme Penggelolaan Sampah,... J.Tek. Ling. 13 (2): 179 - 192 


\subsection{Konsep Metabolisme Pengelolaan Sampah Organik dan Pengujiannya}

\subsubsection{Konsep Metabolisme Pengelolaan Sampah Organik}

Kehidupan perkotaan adalah sebuah ekosistem. Hal itu ditandai dengan adanya tatanan unsur lingkungan hidup yang utuh dan saling mempengaruhi dalam membentuk keseimbangan, stabilitas, produktivitas, dan interrelasi antar komponennya. Sebagai sebuah sistem, kehidupan perkotaan memiliki aliran input dan output material dan energi. Jumlah input material dan energi yang diperlukan umumnya semakin meningkat sejalan dengan pertumbuhan penduduk, perubahan pola konsumsi, gaya hidup, dan meningkatnya arus urbanisasi. Selain itu, jenis, komposisi, dan karakteristik material input yang diperlukan juga semakin beragam.

Seefisien apapun sistem metabolisme perkotaan, selalu terdapat sisa energi atau disebut entropi. Sampah sebagai salah satu bentuk entropi, selain semakin meningkat volumenya juga semakin meningkat jenis, komposisi dan karakteristiknya seiring dengan kemajuan peradaban kota.

Sampah baik itu sampah organik maupun anorganik adalah sumber daya yang dapat dimanfaatkan kembali melalui proses recovery dan daur ulang. Umumnya, upaya pendaurulangan sampah organik dilakukan melalui komposting karena kemudahan dan kesederhanaan sistemnya. Komposting memiliki keistimewaan dapat mengubah entropi sampah yang bersifat merusak lingkungan, menjadi materi organik yang aman, dan kemudian dapat dikembalikan ke alam sehingga kesuburan tanah bisa tetap terjaga serta mendorong terjadinya siklus material.

Proses komposting sendiri merupakan kegiatan yang dinamis yang meliputi kegiatan pemilahan, pengkondisian material, fase aktif fermentasi, fase pematangan, pengayakan, pengemasan, dan distribusi kompos. Di dalamnya terjadi aliran input-output material dan energi. Material input berupa sampah, air dan energi, sedangkan material output berupa kompos, recyclable materials, residu sampah, dan emisi gas.

Apabila dilihat dari dinamika proses dan aliran input-output material dan energinya, maka proses pengelolaan sampah organik melalui komposting menyerupai proses metabolisme yang terjadi pada organisme hidup. Oleh karena itu, istilah metabolisme diadopsi pada istilah pengelolaan sampah organik yaitu menjadi metabolisme pengelolaan sampah organik. Adopsi istilah metabolisme pada pengelolaan sampah organik seperti halnya adopsi istilah tersebut di bidang sosial, ekologi industri dan sebagainya.

Konsep metabolisme pengelolaan sampah organik yang disusun adalah konsep pengelolaan sampah organik menjadi kompos yang mempertimbangkan aplikasi sistem desentralisasi dan sentralisasi komposting. Konsep yang dikembangkan juga mempertimbangkan pendekatan wilayah internal perkotaan sebagai basis analisis supply-demand kompos, seleksi teknologi yang komprehensif, dan analisis aliran input-ouput material serta analisis finansial. Konsep tersebut digambarkan dalam Gambar 1.

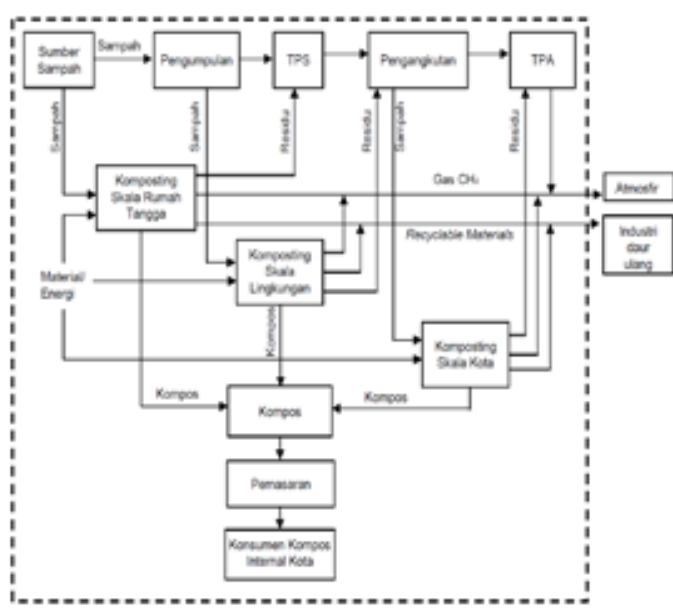

Gambar 1. Metabolisme Pengelolaan Sampah Organik di Wilayah Internal Perkotaan 


\subsubsection{Uji Efektivitas}

Uji efektivitas dilakukan dengan analisis aliran material. Dalam pengelolaan sampah tanpa intervensi pengolahan, sampah yang mengalir ke TPA dari berbagai sumber sampah di Kota Probolinggo berjumlah $46.245 .500 \mathrm{~kg} / \mathrm{tahun}$. Jumlah emisi $\mathrm{CH} 4$ diperkirakan mencapai $2.237 .001 \mathrm{~kg} / \mathrm{tahun}$. Dengan adanya upaya pengolahan sampah melalui komposting didapatkan output produk kompos sebesar $11.222 .816 \mathrm{~kg} / \mathrm{tahun}$. Di dalam produk kompos terkonservasi unsur $\mathrm{N}$ sebesar $49.646 \mathrm{~kg} / \mathrm{tahun}$. Selain itu juga didapatkan output berupa recyclable materials sebesar $8.897 .809 \mathrm{~kg} / \mathrm{tahun}$ yang terdiri atas material kertas, plastik, metal dan kaca. Produksi gas $\mathrm{CH} 4$ secara signifikan dapat diturunkan menjadi 9.254 -18.344 $\mathrm{kg} / \mathrm{tahun}$. Dengan demikian sampah yang tadinya terbuang sia-sia di TPA menjadi material yang termanfaatkan.
Dalam kegiatan komposting baik Skenario 1, Skenario 2, Skenario 3, maupun Skenario 4 dengan input sampah sebesar $46.245 .500 \mathrm{~kg} / \mathrm{tahun}$ menghasilkan nilai output kompos, recyclable materials dan residu yang sama yaitu secara berturutturut $111.222 .816 \mathrm{~kg} / \mathrm{tahun}, 8.897 .809 \mathrm{~kg} /$ tahun dan $4.274 .912 \mathrm{~kg} /$ tahun. Hal tersebut disebabkan karena baik komposting skala rumah tangga, skala lingkungan, maupun skala kota menggunakan teknologi yang pada prinsipnya sama yaitu proses aerobik yang diawali dengan proses pemilahan. Reduksi unsur $\mathrm{N}$ juga sama pada setiap skenario yaitu menjadi $397.115 \mathrm{~kg} / \mathrm{tahun}$. Sementara itu, konservasi unsur $\mathrm{N}$ di dalam kompos juga sama yaitu 49.646 $\mathrm{kg} / \mathrm{tahun}$. Perbedaannya terletak pada konsumsi air selama proses komposting yaitu pada desentralisasi komposting yang melibatkan komposting skala rumah tangga konsumsi airnya sebesar 5.334.765

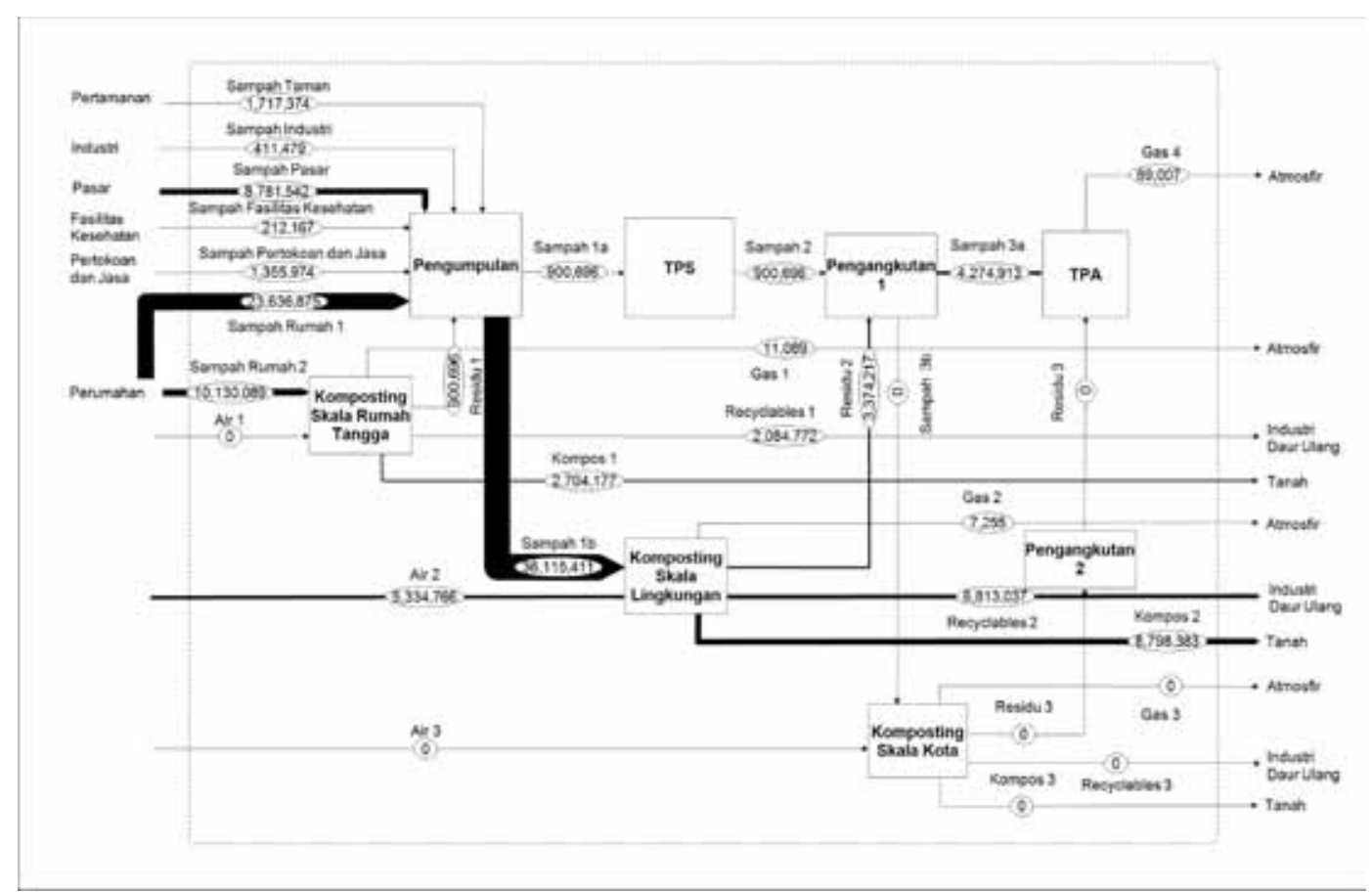

Gambar 2. Analisis Aliran Material dalam Sistem Desentralisasi dan Sentralisasi Komposting Skenario 2. Seluruh angka dalam satuan $\mathrm{kg} / \mathrm{tahun}$.

Keterangan: TPS $=$ Tempat Penampungan Sementara, TPA $=$ Tempat Pembuangan Akhir, tanda kotak $=$ proses 
$\mathrm{kg} / \mathrm{tahun}$. Sedangkan pada sentralisasi komposting konsumsi airnya sebesar $6.804 .784 \mathrm{~kg} / \mathrm{tahun}$.

\subsubsection{Uji Efisiensi}

Biaya pengumpulan dan pengangkutan sampah dari sumbersumber sampah ke TPA tanpa kegiatan komposting digunakan sebagai base line biaya pengelolaan sampah. Pada Skenario 1 dan Skenario 2, yaitu sampah organik dikomposkan secara terdesentralisasi, biaya pengangkutan sampah ke TPA dapat direduksi dari Rp. 1.918.019.874 hingga menjadi Rp. 258.387.630. Hal ini disebabkan karena sebagian besar sampah dimanfaatkan menjadi kompos dan diambil recyclable materials-nya, sehingga yang diangkut ke TPA tinggal residu sampah saja. Sementara itu, pada Skenario 3, yaitu sampah organik dikomposkan secara tersentralisasi, biaya pengangkutan sampah meningkat dari Rp. 1.918.019.874 menjadi Rp. 2.131.219.053. Hal ini disebabkan karena lokasi yang jauh dari sumber sampah dan adanya tambahan biaya pembuangan residu sampah ke TPA. Pada Skenario 4, yang merupakan kombinasi sistem sentralisasi dan desentralisasi, biaya pengangkutan menurun sedikit menjadi Rp. 1.836.908.763. Hal ini disebabkan karena sebanyak $30 \%$ sampah dari perumahan dikelola di sumbernya.

Biaya pengumpulan sampah sistem desentralisasi juga lebih efisien dibandingkan sentralisasi komposting terutama untuk sistem desentralisasi yang melibatkan kegiatan komposting skala rumah tangga. Dengan melibatkan warga mengkomposkan sampah di rumah (Skenario 2), biaya pengumpulan sampah dapat direduksi dari Rp. 1.303.854.392 menjadi Rp. 981.357.505.

Jika dilihat dari total biaya pengumpulan dan pengakutan sampah, desentralisasi komposting yang dilakukan dengan melibatkan masyarakat untuk mengkomposkan sampahnya di rumah (Skenario 2) merupakan kegiatan yang paling efisien yaitu dapat mereduksi biaya pengumpulan dan pengangkutan sampah dari Rp. 3.221.874.266 menjadi Rp. 1.239.745.135. Sementara itu, sentralisasi komposting meningkatkan biaya pengumpulan dan pengangkutan sampah dari Rp. 3.221.874.266 menjadi Rp. 3.435.073.445.

Sementara itu, dilihat dari biaya komposting, sentralisasi komposting relatif lebih rendah biayanya dibandingkan dengan desentralisasi komposting. Hal ini disebabkan oleh banyaknya komposting skala kawasan (14-18 buah) yang harus dibangun dan banyaknya unit komposter (2.610.929 buah) yang harus didistribusikan ke masyarakat. Namun demikian, apabila dibandingkan secara menyeluruh dari biaya pengumpulan, pengangkutan dan komposting, biaya desentralisasi komposting (Skenario 1 dan Skenario 2) masih lebih

Tabel 6. Ringkasan Biaya Pengumpulan, Pengangkutan Sampah dan Komposting

\begin{tabular}{|l|r|r|r|r|r|}
\hline \multirow{2}{*}{ Skenario } & \multicolumn{3}{|c|}{$\begin{array}{c}\text { Biaya Pengumpulan dan Pengangkutan } \\
\text { (Rp/tahun) }\end{array}$} & \multirow{2}{*}{$\begin{array}{c}\text { Biaya Komposting } \\
\text { (Rp/tahun) }\end{array}$} & $\begin{array}{c}\text { Total Biaya } \\
\text { (Rp/tahun) }\end{array}$ \\
\cline { 2 - 4 } & Pengumpulan & Pengangkutan & Total & & - \\
\hline Base Line & 1.303 .854 .392 & 1.918 .019 .874 & 3.221 .874 .266 & & - \\
\hline Skenario 1 & 1.303 .854 .392 & 258.387 .630 & 1.562 .242 .023 & 6.436 .225 .414 & 7.998 .467 .437 \\
\hline Skenario 2 & 981.357 .505 & 258.387 .630 & 1.239 .745 .135 & 6.751 .650 .195 & 7.991 .395 .330 \\
\hline Skenario 3 & 1.303 .854 .392 & 2.131 .219 .053 & 3.435 .073 .445 & 5.445 .136 .211 & 8.880 .209 .657 \\
\hline Skenario 4 & 981.357 .505 & 1.836 .908 .763 & 2.818 .266 .268 & 5.878 .688 .059 & 8.696 .954 .326 \\
\hline
\end{tabular}


efisien dibandingkan dengan sentralisasi komposting (Skenario 3).

Benefit atau manfaat dari kegiatan komposting yang terbesar dicapai oleh Skenario 1 yaitu Rp. 22.196.793.597/ tahun, disusul oleh Skenario 2 yaitu Rp. 22.519.290.484/tahun. Sementara itu, sentralisasi komposting (Skenario 3) manfaat yang dapat dicapai lebih rendah daripada desentralisasi komposting yaitu $\mathrm{Rp}$. 20.323.962.174/tahun. Hal tersebut dapat dilihat pada Tabel 7 .

Dilihat dari nilai net benefit, desentralisasi komposting (Skenario 1 dan Skenario 2) tetap lebih menguntungkan dibandingkan dengan sentralisasi komposting (Skenario 3). Hal tersebut dapat dilihat pada Tabel 8. Dari analisis finansial dapat disimpulkan bahwa desentralisasi komposting dalam metabolisme pengelolaan sampah organik di wilayah internal perkotaan lebih efisien daripada sentralisasi komposting.

\subsubsection{Manfaat Metabolisme Pengelolaan Sampah Organik}

Konsep metabolisme pengelolaan sampah organik memiliki berbagai manfaat baik manfaat lingkungan, finansial, ekonomi, maupun sosial. Manfaat lingkungan antara lain adalah terproduksinya kompos, terrecovery-nya recyclable materials, dan tereduksinya produksi gas $\mathrm{CH} 4$. Produk kompos dapat berfungsi sebagai soil conditioner karena didalamnya mengandung material organik, unsur makro, unsur mikro, dan mikroorganisma yang bermanfaat bagi kesuburan tanah. Pemanfaatan kompos juga menjaga siklus alamiah material organik. Sementara itu, recyclable materials dapat digunakan kembali menjadi bahan baku industri sehingga dapat mengefisienkan penggunaan bahan baku yang dieksploitasi dari alam seperti eksploitasi kayu untuk bahan baku kertas, eksploitasi minyak bumi

Tabel 7. Benefit Kegiatan Komposting

\begin{tabular}{|l|r|r|r|r|}
\hline \multirow{2}{*}{ Benefit } & \multicolumn{4}{|c|}{ Skenario (Rp/tahun) } \\
\cline { 2 - 5 } & 1 & 2 & \multicolumn{1}{c|}{3} & \multicolumn{1}{c|}{4} \\
\hline $\begin{array}{l}\text { Reduksi Biaya } \\
\text { Pengumpulan }\end{array}$ & & 322.496 .887 & & 322.496 .887 \\
\hline $\begin{array}{l}\text { Reduksi Biaya } \\
\text { Pengangkutan }\end{array}$ & 1.659 .632 .244 & 1.659 .632 .244 & -213.199 .179 & 81.111 .111 \\
\hline $\begin{array}{l}\text { Reduksi Biaya } \\
\text { Tipping Fee }\end{array}$ & 2.171 .477 .650 & 2.171 .477 .650 & 2.171 .477 .650 & 2.171 .477 .650 \\
\hline Revenue kompos & 8.417 .112 .583 & 8.417 .112 .583 & 8.417 .112 .583 & 8.417 .112 .583 \\
\hline $\begin{array}{l}\text { Revenue } \\
\text { Recyclable } \\
\text { Materials }\end{array}$ & 9.948 .571 .120 & 9.948 .571 .120 & 9.948 .571 .120 & 9.948 .571 .120 \\
\hline Jumlah Benefit & 22.196 .793 .597 & 22.519 .290 .484 & 20.323 .962 .174 & 20.940 .769 .351 \\
\hline
\end{tabular}

Tabel 8. Net Benefit Komposting pada Berbagai Skenario

\begin{tabular}{|l|r|r|r|r|}
\hline \multirow{2}{*}{ Net Benefit } & \multicolumn{4}{|c|}{ Skenario (Rp/tahun) } \\
\cline { 2 - 5 } & \multicolumn{1}{|c|}{1} & \multicolumn{1}{c|}{2} & \multicolumn{1}{c|}{3} \\
\hline Benefit & 22.196 .793 .597 & 22.519 .290 .484 & 20.323 .962 .174 & 20.940 .769 .351 \\
\hline Biaya & 7.998 .467 .437 & 7.991 .395 .330 & 8.880 .209 .657 & 8.696 .954 .326 \\
\hline Net Benefit & 14.198 .326 .160 & 14.527 .895 .154 & 11.443 .752 .517 & 12.243 .815 .025 \\
\hline
\end{tabular}


untuk bahan baku plastik, ekploitasi bijih logam dan kaca. Tereduksinya gas $\mathrm{CH} 4$ berperan dalam mengurangi pemanasan global.

Metabolisme pengelolaan sampah organik juga memiliki manfaat eksternal berupa reduksi biaya disamenitas TPA, reduksi emisi $\mathrm{CH} 4$ dan reduksi biaya penanganan lindi. Selain itu, metabolisme pengelolaan sampah organik di wilayah internal perkotaan, terutama desentralisasi komposting juga memiliki manfaat sosial berupa: (1) pembukaan lapangan kerja baru bagi penduduk miskin, (2) mendorong kepedulian masyarakat terhadap pengelolaan sampah, (3) persediaan kompos tersebar di dekat konsumen, dan (4) terbukanya peluang usaha skala kecil.

\section{KESIMPULAN DAN SARAN}

\subsection{Kesimpulan}

Kesimpulan dari penelitian ini terdiri dari satu kesimpulan umum dan empat kesimpulan khusus. Kesimpulan umumnya adalah metabolisme pengelolaan sampah organik melalui teknologi komposting di wilayah internal perkotaan adalah metabolisme sistem fisik, sosial, dan ekonomi dari kegiatan pengelolaan sampah yang bercirikan metabolisme antropogenik untuk keberlanjutan kota sedang.

Sementara itu, kesimpulan khusus yang dapat ditarik adalah sebagai berikut:

1. Peta supply-demand kompos di wilayah internal perkotaan adalah peta produksi kompos yang berasal dari berbagai sumber sampah dan kebutuhan kompos dari berbagai konsumen di wilayah internal perkotaan yang bermanfaat bagi penyusunan strategi pemasaran kompos. Melalui analisis supply-demand kompos menggunakan formula matematik dapat diketahui tingkat produksi kompos dan tingkat penyerapan kompos di wilayah internal kota sedang.
2. Perangkat seleksi sistem desentralisasi dan sentralisasi komposting yang dihasilkan berupa seperangkat kriteria yang meliputi berbagai aspek pengelolaan sampah dan dilengkapi dengan acuan penentuan nilai skor. Kriteria yang dihasilkan terdiri dari delapan kelompok kriteria yaitu kriteria teknis persampahan, pendanaan pengelolaan sampah, peraturan daerah terkait pengelolaan sampah, kelembagaan pengelola persampahan, peran serta masyarakat dalam pengelolaan sampah, demografi kota, timbulan dan komposisi sampah, dan tata ruang TPA. Melalui analisis multikriteria pengambilan keputusan yang menggunakan seperangkat kriteria dan acuan penentuan nilai skor, dapat ditetapkan sistem desentralisasi atau sentralisasi komposting yang paling tepat untuk kota sedang.

3. Perangkat seleksi teknologi komposting skala rumah tangga, skala lingkungan dan skala kota yang dihasilkan berupa seperangkat kriteria yang meliputi berbagai aspek dan dilengkapi dengan acuan penentuan nilai skor. Kriteria yang dihasilkan terdiri dari empat kelompok kriteria yaitu kriteria teknis/ teknologi, lingkungan, sosial, dan ekonomi. Melalui analisis multikriteria pengambilan keputusan menggunakan seperangkat kriteria dan acuan penentuan nilai skor, dapat diseleksi teknologi komposting skala rumah tangga, skala lingkungan dan skala kota yang paling tepat untuk diaplikasikan di kota sedang.

4. Konsep metabolisme pengelolaan sampah organik melalui teknologi komposting di wilayah internal perkotaan dapat disusun dengan mempertimbangkan lima hal utama yaitu pendekatan wilayah internal perkotaan sebagai basis pemasaran kompos; sistem desentralisasi dan sentralisasi komposting; teknologi 
komposting skala rumah tangga, skala lingkungan dan skala kota; sistem metabolisme antropogenik; dan elemen-elemen pengelolaan sampah. Konsep tersebut dapat diketahui efektivitas dan efisiensi penerapannya di kota sedang melalui analisis aliran material sampah dan analisis finansial pengelolaannya.

\subsection{Saran}

\section{Penelitian ini menyarankan:}

1. Desentralisasi komposting dapat dilakukan secara bertahap sesuai dengan kemampuan pemerintah kota dengan penetapan target-target yang rasional dan dilaksanakan dengan komitmen tinggi.

2. Terkait dengan upaya pemasaran kompos, perlu dilakukan sosialisasi, kampanye, penyuluhan manfaat kompos dan tata cara aplikasinya serta pembangunan demplot-demplot uji coba pemanfaatan kompos.

3. Sebaiknya dilakukan program yang bersifat multiyears untuk mendidik dan membina masyarakat agar terjadi perubahan persepsi dan perilaku terhadap sampah.

4. Konsep metabolisme pengelolaan sampah organik di wilayah internal perkotaan perlu diujicobakan pada tipologi kota besar dan metropolitan yang memiliki kompleksitas permasalahan sampah yang lebih tinggi.

\section{DAFTAR PUSTAKA}

1. Lapid, D., Christopher C. Ancheta, \& Theresa J. Villareal. (1996). Composting in the Philipppines. Waste. Netherland.

2. CPIS. (1992). Panduan Praktis Pembuatan Kompos. Center for Policy and Implementation Studies, Jakarta.
3. Drescher S., Müller C., Kubrom, T., Mehari, S., Zurbrügg C., \& Kyzia S. (2006b). Decentralised composting Assessment of viability through combined material flow analysis and cost accounting. Proceedings, Orbit 2006 Conference, Weimar, hal. 1215-1227.

4. Drescher S., \& Zurbrügg C. (2004). Decentalized Composting in India dalam Buku Sustainable Composting, Case Studies and Guidelines for Developing Countries. Water, Engineering and Development Center, Loughborough University. Hal. 15-27.

5. KLH. (2006). Laporan Program Subsidi Kompos WJEMP. Kementerian Negara Lingkungan Hidup, Jakarta

6. Department for Communities and Local Government. (2009). Multi-Criteria Analysis: a Manual. Communities and Local Government Publications, West Yorkshire.

7. CIFOR. (1999). Panduan untuk Pengembangan, Pengujian dan Pemilihan Kriteria dan Indikator untuk Pengelolaan Hutan Lestari. Center for International Forestry Research

8. Kyoungsoo, Kwon. (2005). Financial Feasibility of Composting Market Waste in Vientiane, Lao PDR. Thesis Master of Engineering, Department of Civil Engineering, University of Toronto.

9. Badan Lingkungan Hidup (BLH) Kota Probolinggo. (2010). Profil Persampahan Kota Probolinggo. Pemerintah Kota Probolinggo.

10. Pemerintah Kota Probolinggo. (2005). Laporan Akhir Studi Potensi Sumber Sampah dan pemanfaatannya di Kota Probolinggo. Pemerintah Kota Probolinggo. 
11. Bagchi, A. (2004). Design of Landfill and Integrated Solid Waste Management. John Wiley and Sons, Inc., New Jersy, USA.

12. Xinlei $X u$, Victor Rudolph \& Paul F. Greenfield (1999). Australian Urban Landfills: Management and Economics. Waste Management Research 1999; $17 ; 171$

13. Badan Pusat Statistik Kota Probolinggo. (2010). Hasil Sensus Penduduk 2010 Kota Probolinggo. Kota Probolinggo

14. World Bank. (1981). World Bank Report on Appropriate Technology for Water Supply and Sanitation. Vol. 10, 1981.

15. Gaur, A.C. (1994). A Manual of Rural Composting. FAO. Perserikatan Bangsa-Bangsa.

16. Sulaksono, B., \& Budiyati, S. (1994). Usaha Daur Ulang dan Produksi Kompos (UDPK) sebagai Alternatif Penanganan Sampah Kota di Indonesia. Lokakarya Pengembangan Penggunaan dan Pemasaran Kompos dan Produk Daur Ulang Lainnya. Kantor
Menteri Negra Lingkungan Hidup. Jakarta, 6 Desember 1994.

17. DKLH Bidang Kebersihan. (2006). Laporan Tahunan 2006. DKLH Pemerintah Kota Probolinggo. Pemerintah Kota Probolinggo. (2005

18. Pemerintah Kota Probolinggo. (2010). Buku Putih Sanitasi Kota Probolinggo Tahun 2010. Pemerintah Kota Probolinggo.

19. Peraturan Daerah Nomor 5 Tahun $\overline{2010}$ tentang Pengelolaan Sampah, Pemerintah Kota Probolinggo

20. Peraturan Daerah Nomor 17 Tahun 2002 tentang Kebersihan, Pemerintah Kota Probolinggo

21. Surat Keputusan Dinas Kebersihan dan Lingkungan Hidup (DKLH) Kota Probolinggo No. 712 tahun 2005 tentang Standar Pelayanan Publik tentang UPTD Komposting.

22. UPTD Komposting DKLH Kota Probolinggo. (2008). Laporan Tahunan 2008. Kota Probolinggo. 